Article

\title{
A Mixed-Method Study of Design Practices and Designers' Roles in Sustainable-Minded Clothing Companies
}

\author{
Essi Karell *(D) and Kirsi Niinimäki (D) \\ Department of Design, School of Arts, Design and Architecture, Aalto University, 02150 Espoo, Finland; \\ kirsi.niinimaki@aalto.fi \\ * Correspondence: essi.karell@aalto.fi
}

Received: 19 April 2020; Accepted: 4 June 2020; Published: 8 June 2020

check for updates

\begin{abstract}
The way in which the current fashion industry operates needs to fundamentally change. In this endeavour, designers are considered central figures throughout the sustainable fashion literature. However, too little is known about clothing designers' practical contributions to sustainability. Therefore, this study investigates how sustainability is integrated into design practices in sustainable-minded clothing companies and determines the role of clothing designers in this respect. A mixed-method study was conducted based on a sequential exploratory strategy. The data were collected in two stages: a preliminary phase based on five expert interviews and a survey phase, which involved 31 clothing designers from around Europe. The data analysis was also divided into two phases: thematic analysis of the interviews and content analysis of the survey. The findings indicate that the sustainable design practices within these companies predominantly focus on material choices and aspects that support product longevity. Yet, there is little empirical evidence to support claims regarding garments' true longevity. Knowledge regarding materials, recycling and best practices is also lacking among clothing designers. Lack of knowledge and company strategies frequently dictate and restrict the design work. This further highlights the fact that designers' opportunities to influence environmental and social change are more limited than earlier literature suggests.
\end{abstract}

Keywords: sustainability; sustainable design; sustainable fashion; clothing design; fashion design; design practice; mixed-method

\section{Introduction}

The global fashion industry requires a massive systemic transformation. The fashion business' pursuit of growth, based on exploiting the earth and its inhabitants, has long been questioned [1,2]. Today, the environmental and societal problems that have risen from the numerous operations within fashion supply chains are widely acknowledged and addressed both inside and outside of the fashion industry [3,4]. The development of sustainable alternatives (production methods, materials, design practices and business models) is thriving [4], and a significant number of fashion/clothing brands of different sizes and geographical locations are committing to changing the course of the industry $[5,6]$. However, despite the multiple initiatives and actions taken, the fashion industry seems resistant to change. As stated in the Pulse of the Fashion Industry 2019 Update: "Fashion companies are not implementing sustainable solutions fast enough to counter-balance negative environmental and social impacts of the rapidly growing fashion industry" [7]. This can be witnessed in the continuous increase in the production and consumption volumes of garments [8]. The overall demand for clothing production is expected to grow by $2 \%$ every year [9].

In the pursuit of a sustainable fashion system (meaning ethically and ecologically sound production and consumption practices based on real demand), even more changes and actions are needed at different 
societal levels: legislation, infrastructure, technology, education, business, design and consumption $[7,8]$. Design plays a central role in this attempt. According to Tischner and Charter, as much as " $80 \%$ of the environmental and social impacts of a product, incurred throughout its whole life-cycle" could be influenced already in the product design and development phase [10] (p. 120). This is an estimate that has persisted within sustainable design research already for two decades and has become part of the European Commission's Sustainable Product Policy [11]. Studies of sustainable fashion also refer to this figure while noting the designer's determinant role in sustainability endeavours [12-14]. Indeed, as also observed by Kozlowski, Bardecki and Searcy [15] (p. 1), fashion designers are "repeatedly declared as key agents of change in the transformation to a sustainable fashion industry". However, little is known about fashion designers' actual contributions to sustainability in sustainable-minded clothing companies of different sizes.

Numerous studies have focused on sustainable fashion design practices, but none from this angle. Many of them provide meaningful information on the best practices, challenges and opportunities in sustainable fashion design $[12,13,16-20]$, as well as designers' understanding and impressions of sustainability [12-14]. These studies offer clues as to the designers' roles in and influence on sustainability, but they are often limited in scope. Most are based on a handful of interviews or individual case studies [13,16-19] conducted in specific contexts such as micro- or small-sized companies $[13,16,18]$. Oftentimes, these studies are also limited to one sustainable strategy or approach, such as slow fashion [16,20], design for longevity [19,21], zero waste design [22], upcycling [23] and design for remanufacturing [24]. While these studies provide important insights into sustainable design practices and processes, their discussions on how much impact designers actually have in terms of environmental and social sustainability remain inadequate.

Against this background, this study zooms in on sustainable-minded clothing companies of different sizes and the working realities of their designers. By sustainable-minded, we refer to companies that claim to conduct their business responsibly and communicate a sustainable vision. The primary objective of the study is to extend the understanding of sustainable clothing design practices and shed light on designers' work in sustainable-minded company contexts. The following research questions guided the study:

- How is sustainability integrated into the design practices of sustainable-minded clothing companies?

- What is the role of a clothing designer in this respect?

Through these questions, we come to discuss what the designers' influences on the environmental and social impacts of fashion are. To accomplish the research goal, a mixed-method study was conducted in two separate phases, described in the following sections. The research began with a preliminary study presented in the PLATE conference 2019 [25]. In this preliminary phase, five clothing designers were interviewed about their sustainable design practices and concerns about sustainability. Building on this preliminary step, a survey was developed to reach a wider sample of clothing designers. The background literature presents some of the current discussions related to sustainable fashion design and the challenges within.

\section{Sustainability in Fashion Design}

Regarding sustainability, design can influence numerous aspects in the production and consumption of products; for example, by fulfilling users' needs, by its selection of materials and production technologies and by considering the entire product lifecycle [10]. As of all industrial products, this can also be expected of fashion design. What is traditionally expected of fashion designers, however, does not include sustainable perspectives. Instead, fashion designers can be seen as translators of creative ideas into profitable products, requiring understanding of consumer needs and communication skills within the sample making [26]. Commonly, designers employed by clothing companies work on the basis of a design brief, which is limited by many factors, such as brand aesthetics and collaboration with manufacturers [27]. In these 
routine circumstances, sustainable strategies tend to be ignored if sustainable concerns are not embedded within the design brief [27].

In order to meet the demand for sustainability, fashion design scholars have actively studied alternative design approaches and opportunities for integrating sustainability into fashion design processes. A significant strand of this research has focused on sustainable design strategies and principles in the form of academic research publications [28-33], as well as books that popularise scholarly work for more practical purposes [34-40]. During the last decade, a growing number of practical and conceptual design tools and guides have also been developed to further help clothing designers implement sustainability in practice [41-45]. The underlying message across this literature (and developed tools) is that considering the whole garment lifecycle already in the design phase could help fashion companies decrease the pressure on the environment and consider the societal implications of their production. Considering the constant increase in the production and consumption of clothes [8], the key factor (if not the foremost) is yet to reduce the overall speed and volume of clothing production $[29,33,46]$. The following instances advocate this notion. As stated in the report by The Waste and Resources Action Programme (WRAP), "extending the average life of clothes by just three months of active use per item would lead to a $5-10 \%$ reduction in each of the carbon, water and waste footprints" [47] (p. 2). This is in line with the European Commission's Waste Framework Directive, which positions prevention at the top of the waste hierarchy, followed by reuse and recycling [48].

One of the most discussed sustainable design strategies addressing the problem of clothing volumes is design for longevity [33], which can be seen as an umbrella term for multiple other strategies [21]. These strategies include (but are not limited to) physical and emotional durability, timeless design, slow fashion, trans-seasonality, co-creation with users, multifunctionality, adjustability, modularity and production on demand $[21,30,49,50]$. In order to communicate such concepts in concise formats to fashion practitioners, various toolkits and guidelines have become popular in transferring knowledge from academia to industry, as discussed by Connor-Crabb, whose PhD summarises many of the currently available tools embracing product longevity [21] (p. 77). Detailed accounts of what practical aspects to consider in terms of product longevity are also presented in "Sustainable Clothing: A practical guide to enhancing clothing durability and quality", developed and perfected in recent years by WRAP researchers in collaboration with the fashion industry [44].

In theory, employing sustainable design tools and strategies for product longevity should guide designers to diminish the need for new clothes, reduce production volumes, and finally minimise the myriad environmental and social effects. However, as Connor-Crabb states, it is questionable whether such design tools are "at all effective, particularly as so few are used in industry contexts beyond the academics who develop and test them" [21] (p. 225). In a similar vein, there are questions regarding the applicability of the different sustainable design strategies. As Fletcher emphasises, strategies for longevity are always limited by usage practices, which can be difficult to influence through traditional design processes [51]. The limitations of design for longevity are also pointed out by Laitala, Boks and Klepp, who evidenced that even poorly suited products can be used for a long time and vice versa [52]. What actually happens to the garments after the point of purchase is not necessarily in line with the intended garment lifecycle. Hence, more empirical studies that could validate the functionality of these strategies are needed [33,53].

A growing number of sustainable fashion scholars have also shown interest in the circular economy model (CE) and its potential to accelerate the industry's transformation, largely based on the cradle-to-cradle ideology [54]. According to such ideology, all materials, products and their components should infinitely circulate in closed loops, providing numerous possibilities to add value to products and materials while reducing the need for virgin materials [55]. Design for longevity also plays an important part in a circular economy and is often simultaneously discussed with alternative business models and additional services [8,56,57]. In addition, a circular economy places weight on design for recycling [8], which is currently enjoying increasing academic attention [58-62]. For practical 
purposes, new tools and guidelines have been (and are constantly being) developed within the industry to support circular fashion design [63-65].

Even though the theoretical and practical understanding of sustainable (and circular) fashion design practices is increasing, there are multiple obstacles to implementing sustainability in the design process. These include (but are not limited to) company capacity and mindset $[12,13,60]$, industry practices and norms $[12,13,58,60]$, consumer behaviour and expectations $[12,13,60]$ and technological restrictions $[13,58,60,61]$. In the context of small companies, for example, sustainability seems to be driven by designers' personal devotion, and therefore their moral ambitions may override large profit margins [13]. Commonly, this relates to materials—organic and recycled fabric alternatives, for instance, are often more expensive than standard options [58] as well as harder for smaller companies to obtain [66]. This means that companies are obliged to prioritise their sustainable approaches and balance between values and profit [13]. Company strategies are substantially important in this respect. They steer financial targets and budgets, collection structures and the whole clothing design process [13,27,60]. Meanwhile, studies also suggest that clothing designers lack the knowledge of sustainable design strategies and of sustainability in general [12-14,62]. Although some designers are aware of particular design strategies (e.g., cradle-to-cradle), only few have tried to implement them in their design and production processes [13].

\section{Data and Methods}

To extend our knowledge of clothing design practices in sustainable-minded clothing companies, this study applied a mixed-method approach, combining qualitative and quantitative forms of research [67]. The general advantages of mixed-method approaches are manifold. For example, by combining qualitative and quantitative methods, researchers can simultaneously address exploratory and confirmatory questions, as the former may be considered more appropriate for hypothesis generation and the latter for hypothesis testing [68]. Secondly, the results achieved by these two approaches may be complementary to each other, allowing for a better understanding of an issue than could be reached by separately using one method, and therefore allowing for more valid conclusions by data triangulation [68,69]. Thirdly, a mixed-method approach may also enable researchers to determine significant contradictions that further theoretical insights [68].

In the present study, the primary motivations to combine qualitative and quantitative methods were pragmatic. The study began with qualitative data collection and analysis based on five semi-structured expert interviews of clothing designers employed by sustainable-minded clothing companies. Already at this stage, recruiting designers for the study proved to be challenging due to companies' time constrains. In addition, the topic of the study is certainly quite sensitive, as companies may feel that their practices are judged in some way. To overcome these potential barriers (time and trust), an online survey was developed with the intention of lowering the threshold for the designers to participate in the study in their own time, while securing their anonymity. The purpose was to gain a larger study sample that could both complement and expand the understanding already acquired through the expert interviews (the survey eventually reached 31 clothing designers). Figure 1 visualises this two-phase procedure based on a sequential exploratory strategy, which is considered appropriate in circumstances in which certain elements emerging from the qualitative research phase need further clarification or validation [67] (p. 14). This was exactly the case in the present study.

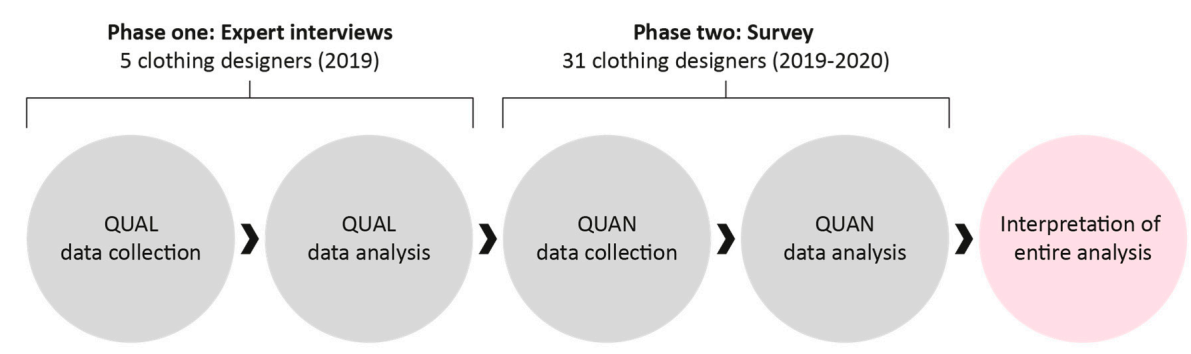

Figure 1. Sequential exploratory strategy followed in the study. Illustration: Authors. 
The sequential exploratory strategy was also regarded as important when it came to finalising the overall research questions and those posed to the research participants. The survey design, shown in Appendix A, was largely developed on the basis of the analysis of the expert interviews. Some well-defined open-ended interview questions were copied into the survey as such, while others were reformulated or excluded, taking into account the nature of the online survey format. Some clarifying questions related to quality aspects, the definition of sustainability and the usage of different design strategies, tools and approaches were also added. The results of the expert interviews (i.e., concerns stated by the designers) also enabled us to formulate statements on which the survey respondents could consider their stance. Sections 3.1 and 3.2 elaborate separately on the expert interviews and the survey. The discussion section bridges the findings of these two phases and discusses their implications.

\subsection{Phase One: Expert Interviews}

\subsubsection{Data Collection and Analysis}

The preliminary phase of the current research (including qualitative data collection, analysis and reporting) took place between January and June 2019 and was presented at the PLATE conference in 2019 under the title "Deconstructing the Clothing Design Process for a Circular Economy" [25]. This phase aimed to map the design practices of sustainable-minded clothing companies, and the designers' main concerns in relation to sustainability and circularity. To address these issues, a purposive sampling strategy was utilised, and only companies with a clearly formulated sustainable vision were contacted via email requests. Five clothing designers from three established clothing SMEs in Northern Europe agreed to participate in the study. Table 1 presents a summary of the interviewees.

Table 1. Information regarding interviewees and represented companies [25].

\begin{tabular}{ccc}
\hline Position & Experience in the Field & \multicolumn{1}{c}{ Description of Employer Company } \\
\hline $\begin{array}{c}\text { Design } \\
\text { Manager/Designer }\end{array}$ & 18 years & $\begin{array}{l}\text { Clothing and lifestyle brand for adults; focus on organic } \\
\text { and recycled materials, clothing longevity and repair }\end{array}$ \\
\hline $\begin{array}{c}\text { Development } \\
\text { Manager/Designer } \\
\begin{array}{c}\text { Sustainability } \\
\text { Advisor/Designer }\end{array}\end{array}$ & 20 years & $\begin{array}{l}\text { Clothing and lifestyle brand for children and adults; } \\
\text { focus on organic and recycled materials and clothing } \\
\text { longevity }\end{array}$ \\
\hline $\begin{array}{c}\text { Head Designer } \\
\text { Assistant Designer }\end{array}$ & 5 years & $\begin{array}{l}\text { Clothing brand for children and adults; focus on organic } \\
\text { materials, clothing longevity and user-centred design }\end{array}$ \\
\hline
\end{tabular}

Semi-structured expert interviews [70], each lasting for 60-90 min, were conducted with the designers either face-to-face or via Skype calls. The interviews addressed several themes, which are listed below.

- Background information (participant and company)

- Designer's role and responsibilities

- Design process

- Designer's sustainability knowledge

- Sustainability in the design process

- Challenges when designing long-lasting/recyclable garments

- Designer's needs in terms of sustainability

During the interviews, the designers were also shown different product types in order to deepen the conversation on various product properties from the sustainability and circularity perspective and on the designers' opportunities to influence such aspects. The interview protocol is described in more detail in the conference paper [25]. 
The interviews were audio recorded and transcribed. The transcriptions were analysed through thematic analysis [70]. Provisional coding [71] was conducted on the basis of the challenges and concerns (company strategy, knowledge, technology, market and material) identified in earlier studies, as discussed in Section 2. By reviewing the aspects that either limit or help clothing designers to apply sustainable design principles, we were able to look into the patterns of current practices and the most critical issues among the interviewed designers. These were finally collated into three general themes: sustainable mindset, sustainable design practice and sustainable design knowledge. These preliminary issues are summarised in the next section. The conference paper [25] provides more detailed descriptions of these results.

\subsubsection{Results: Expert Interviews}

Regarding a sustainable mindset, all three represented companies had set sustainability visions or criteria for their design and business operations since their establishment. All of them aimed for physical and aesthetic durability, focused on sustainable materials and clearly allocated resources to sustainability (e.g., specialised staff for sustainability, sustainability education). The companies had also developed guidelines for their designers. One company, for example, provided designers with a list of materials that the company had internally approved from a sustainability perspective.

Materials seem to steer the sustainability-related discussion and guide design practices the most. The current material offering is the greatest concern, as this excerpt demonstrates: "Finding suitable materials is the main challenge. It's a huge task to find materials that truly function in our products and that best fulfil our criteria from the existing alternatives-all of which are actually bad." To overcome this challenge, two companies actively participated in material development, whereas one company had made a strategic decision to rely purely on their suppliers' offerings in order to guarantee stable quality, which is critical from the product longevity perspective. To further support product longevity through design, the designers tried to avoid trends and favoured timeless design. Here, product reusability is also taken into account; multiple sizing, transformability or loose pattern design are some practical means, especially in children's wear. One company also provided a repair service for their customers. However, even if companies aim for long-lasting design, they have little knowledge of the actual usage phase and lifecycle of their products.

Regarding sustainable design knowledge, designers also seem to lack information on various other issues. For instance, the designers were not aware of existing sustainable design strategies or tools. Although the companies' practices reflected sustainable design strategies such as design for longevity and design for reuse, knowledge of these terminologies was limited. Meanwhile, a profound understanding of how to increase the circularity of materials and products seemed to be lacking. The designers did not know the current limitations of recycling, which is crucial information for material choices and product structures. The circular economy and design for recycling are relatively new aspects for designers. More applied knowledge is required in order to consider such issues at the level of product design.

\subsection{Phase Two: Survey}

The preliminary phase provided a glimpse of the currently employed sustainable design strategies together with the concerns and challenges that clothing designers face. Due to the small interview sample, however, more data were necessary to further investigate the extent of the emerging issues. For this purpose, an online survey was designed to reach a larger group of clothing designers.

\subsubsection{Data Collection}

The survey phase of the research (which included planning, dissemination, analysis and reporting) took place between November 2019 and April 2020. As in the preliminary phase, purposive sampling strategy was used, targeting clothing designers who worked at European clothing companies, which aimed to conduct their business responsibly and communicate their sustainability vision. Company size or age did not matter in the survey. Following these criteria, a list of suitable companies 
was compiled on the basis of the authors' professional knowledge and further extended by browsing through ratings of ethical brands (e.g., Good on You) and online stores dedicated to sustainable fashion. Altogether, 178 companies (of which 41 were Finnish) were contacted and asked to circulate the survey among their clothing designers. Most of the companies were contacted via email or online contact forms. Whenever possible, the designers were approached directly via personal email or a LinkedIn message. In addition, the survey invitation was posted as an inquiry on Sourcebook, a B2B online sourcing platform for the textile industry [72].

\subsubsection{Data Analysis}

The analysis of the survey was conducted in three parts. The first part focused on the open-ended survey questions. Here, a qualitative content analysis was applied [73] to identify the common features in the textual responses. Despite some preconceptions regarding what the survey data might reveal based on the results of the preliminary phase, a data-driven approach was chosen for the analysis with the purpose of seeing whether similar patterns emerged from the survey data. The process started by coding aspects that either directly or indirectly related to clothing designers' working practices and conditions (by using ATLAS.ti software). This first cycle of coding was based on descriptive coding and sub-coding, the latter of which is considered particularly appropriate for content analysis [71] (pp. 74-80). This coding procedure produced multiple codes which were refined and combined by reviewing the data several times. Afterwards, the intensity of the generated codes was examined, which helped create an understanding of the most relevant issues concerning designers' daily work with respect to sustainability. The most frequently mentioned aspects led us to collate the refined codes into relevant categories and sub-categories.

In the second part, we looked at the background information of the survey respondents and the companies they represented. This phase was straightforward and provided relatively univocal information on the survey sample, which is further described in the next section. The third part addressed questions that dealt with the respondents' knowledge of sustainable design strategies and tools, such as the companies' approaches to sustainability and the respondents' views of the statements we had formulated on the basis of the preliminary findings. These questions were based on scale selection and provided numeric results, which were then contrasted with the intensity of responses from the open-ended survey questions. For example, many of the researcher-generated statements touched upon issues that the respondents also reported in their textual answers. Hence, we were able to naturally mix the textual and numeric data in the analysis, as demonstrated in the Survey Results section.

\subsubsection{Survey Sample}

In summary, 31 respondents participated in the survey between December 2019 and February 2020. Most of the survey respondents $(n=28)$ worked as clothing designers in the company they represented. Three other respondents held higher positions (e.g. Head of Design), which did not include designing per se, but which required broad knowledge of clothing design processes and product development. Hence, these three non-designers were also considered suitable participants for the study. Regarding education, almost all the survey respondents $(n=29)$ had studied fashion/clothing design at some educational level. Those without corresponding education were self-taught and experienced clothing professionals with backgrounds in other creative fields.

Regarding the represented companies, a common denominator was the pursuit of sustainability. Apart from this, the companies differed from each other in many respects: size, country of origin, age, sector, distribution and manufacturing operations. Four companies provided rental services and only one company collected back old products for resale. The rest of the companies distributed their products through wholesale and/or retail. A few also provided design as a service. Roughly half of the represented companies were located in Finland $(n=17)$, whereas the rest $(n=14)$ were 
dispersed throughout Europe. Table 2 complies the background information on the survey respondents and the represented companies and shows the diversity within the survey sample.

Table 2. Information on survey respondents and represented companies.

\begin{tabular}{|c|c|c|c|}
\hline & Position & Experience as Designer & Education \\
\hline Respondents $n=31$ & $\begin{array}{c}\text { Fashion designer } n=28 \\
\text { Owner } n=12 \\
\text { Founder } n=9 \\
\text { Creative director } n=8 \\
\text { Print designer } n=6 \\
\text { Product manager } n=4 \\
\text { Production coordinator } n=5 \\
\text { CEO } n=4 \\
\text { Pattern maker } n=3 \\
\text { Textile designer } n=3\end{array}$ & $\begin{array}{c}\text { Less than a year } n=1 \\
1-3 \text { years } n=5 \\
4-5 \text { years } n=5 \\
6-10 \text { years } n=8 \\
11-15 \text { years } n=2 \\
16-20 \text { years } n=5 \\
\text { More than } 20 \text { years } n=5\end{array}$ & $\begin{array}{l}\text { Fashion/clothing design } \\
\text { studies } n=29\end{array}$ \\
\hline \multirow{4}{*}{ Company } & Size & Country of Origin & Age \\
\hline & $\begin{array}{c}\text { Micro } n=14 \\
\text { Small } n=7 \\
\text { Medium } n=2 \\
\text { Large } n=8\end{array}$ & $\begin{array}{c}\text { Finland } n=17 \\
\text { Scandinavia } n=4 \\
\text { Germany } n=3 \\
\text { United Kingdom } n=3 \\
\text { The Netherlands } n=1 \\
\text { Estonia } n=1 \\
\text { Italy } n=1 \\
\text { Spain } n=1\end{array}$ & $\begin{array}{c}\text { Less than a year } n=1 \\
1-3 \text { years } n=6 \\
4-5 \text { years } n=2 \\
6-10 \text { years } n=4 \\
11-15 \text { years } n=7 \\
16-20 \text { years } n=1 \\
\text { More than } 20 \text { years } n=10\end{array}$ \\
\hline & Distribution & Manufacturing & Sector \\
\hline & $\begin{array}{l}\text { Wholesale } n=20 \\
\text { Retail } n=29 \\
\text { Rental } n=4 \\
\text { Resale } n=1\end{array}$ & $\begin{array}{c}\text { In-house } n=4 \\
\text { Domestic } n=11 \\
\text { Neighbouring countries } \\
\quad n=10 \\
\text { Within the EU } n=15 \\
\text { Outside the EU } n=17 \\
\quad \text { (Asia } n=13 \text { ) }\end{array}$ & $\begin{array}{c}\text { Womenswear } n=23 \\
\text { Menswear } n=15 \\
\text { Children's wear } n=8 \\
\text { Sportswear } n=6 \\
\text { Workwear } n=5 \\
\text { Outdoor clothing } n=2\end{array}$ \\
\hline
\end{tabular}

The over-representation of Finnish companies was not intentional. However, taking into account the research questions, as well as Finland's strong national efforts towards a circular economy, the oversampling was not considered a significant problem. In fact, Finland is one of the leading countries in terms of the circular economy, as it introduced the world's first national circularity road map in 2016 [74]. Meanwhile, the Finnish Textile and Fashion Association has also provided significant advocacy actions related to sustainable and circular practices at the national level in recent years [75]. Based on this, one can expect sustainable design practices to already be implemented to some extent, or at least be underway, in many Finnish clothing companies. This can justify the strong share of Finnish companies within the current study.

\section{Survey Results}

The primary objective of the survey was to extend the current understanding of how sustainability is integrated into the design practices of sustainable-minded clothing companies. In order to fully address the research question, we started by reviewing how the survey participants themselves perceived sustainability, and how important they thought certain sustainability approaches were to the companies they represented. These are relevant concerns that can be expected to influence the actual work of designers. On the basis of these findings, we finally report the results related to designers' roles and practices. 


\subsection{Defining Sustainability}

"What does sustainability mean to you as a designer?" was presented as an open-ended question and received answers from all of the respondents $(n=31)$. The most often mentioned attributes of sustainability are summarised in Table 3. Commonly referred to dimensions of sustainability, such as social responsibility $(n=19)$ and environmental responsibility $(n=16)$, were mentioned by roughly half of the respondents, whereas economic sustainability was only stressed by three. Social responsibility was the most referred to attribute among the participants, followed by material choice $(n=17)$. Materials were mentioned with respect to responsible production (e.g., low environmental impact of materials), end-of-life (recyclability and biodegradability), and physical durability. The latter can be considered a precondition of product longevity, which was also addressed by 17 respondents. Most comments on product longevity were in the context of use and maintenance. Product longevity is also closely connected to timeless design, which was separately mentioned by seven respondents. However, product longevity and timeless design were often discussed together as the following extract demonstrates: "Sustainability is responsible production, durable and good-quality products, which really withstand use and timeless design so there is no need to renew clothes every season."

Table 3. What does sustainability mean to you as a designer?

\begin{tabular}{ccl}
\hline Attributes & Respondents (n) & \multicolumn{1}{c}{ Examples } \\
\hline Social responsibility & 19 & $\begin{array}{l}\text { Ethical production, respect for/well-being of } \\
\text { people, working conditions, human rights, fairness }\end{array}$ \\
\hline Responsible material choice & 17 & $\begin{array}{l}\text { Environmentally friendly, natural, recycled, } \\
\text { durable, high-quality, certified biodegradable, } \\
\text { recyclable materials }\end{array}$ \\
\hline Product longevity & 17 & Long-lasting, durable, quality, repairable, reusable \\
\hline $\begin{array}{c}\text { Environmental } \\
\text { responsibility }\end{array}$ & 16 & $\begin{array}{l}\text { Balance with nature, respect for/well-being of } \\
\text { nature, saving resources, reducing environmental } \\
\text { impact }\end{array}$ \\
\hline Work in progress & 10 & $\begin{array}{l}\text { The future, "step by step, day by day", "should be } \\
\text { the norm" }\end{array}$ \\
\hline Lifecycle thinking & 8 & $\begin{array}{l}\text { Recyclability, circular economy, "considering } \\
\text { the whole life cycle" }\end{array}$ \\
\hline Timeless design & 7 & $\begin{array}{l}\text { Aesthetically long-lasting, seasonless, slow } \\
\text { fashion, no trends }\end{array}$ \\
\hline Fit for purpose & 7 & $\begin{array}{l}\text { Product has relevance/function/reason, "meets a } \\
\text { true demand", "has value in the eyes of } \\
\text { the customer" }\end{array}$ \\
\hline Economic sustainability & 3 & \begin{tabular}{l} 
Viability of one's own company \\
\hline
\end{tabular} \\
\hline
\end{tabular}

In addition, many respondents $(n=9)$ mentioned lifecycle thinking and stressed the importance of understanding the various processes from fibre production to the end-of-life phase. As one respondent described: "To me, sustainability in the clothing industry means lifecycle thinking, which in addition to the product development process includes material production as well as recycling and possible disposal of the garment." Some respondents $(n=7)$ also associated sustainability with the usefulness and functionality of products. As one participant wrote, "a sustainable garment is primarily produced on demand, it has a function, it works, and it is long-lasting". In Table 3, we refer to this attribute as fit for purpose, which again links to product longevity. However, this attribute clearly stood out on its own in the data with an emphasis on the instrumental aspects of products.

Generally, the survey respondents' definitions of sustainability were quite vague, which can be expected when collecting perspectives through a survey, but also because of the ambiguity of the term. Whereas sustainability is often addressed on the basis of the notion of triple-bottom-line [76], 
the nature of the concept can be seen as rather fluid, which was also observed in the designers' responses. For example, many $(n=10)$ referred to sustainability as something ongoing or something to strive for, which we refer to as "work in progress" in Table 3. Descriptions such as "one step at a time, day by day" and "I believe sustainability should be the norm for all industries" imply that the efforts towards sustainability, whatever that may mean on individual bases, are yet to be taken from the design perspective.

\subsection{Sustainability in the Company}

The survey respondents were also asked to shortly describe the main purpose of the company they worked for. Sustainable company mindset was explicitly present in the descriptions, as 21 respondents described their company as sustainable, responsible or ethical. Minor references were made to functionality $(n=5)$, high quality $(n=6)$ and product longevity $(n=5)$. As these descriptions provide only a narrow view of the companies' sustainable approaches, respondents were also asked to give their opinion on how important they perceived certain sustainability aspects to be for the company they represented. The findings suggest that the companies approached sustainability in many respects, which is in line with the many dimensions linked to the designers' definitions of sustainability. These aspects are presented in Figure 2 in order of popularity.

The findings indicate that the most important approaches among the companies are linked to product longevity (high quality/physical durability and timeless design), material selection (use of certified, recycled and organic materials) and social responsibility (safe working conditions, fair living wages and supply chain transparency). Interestingly, the circular economy, which currently seems to steer much of the sustainable fashion-related discussions, scored quite low, as did the recyclability of products, additional services, redesign/upcycling and alternative business models, all of which can be considered crucial elements, especially if aiming to move towards a circular economy.

\subsection{Company Mindset vs. Designer's Role}

Regarding the company mindset, most of the respondents $(n=26)$ thought that the company they worked for had a clear vision of sustainability. Only five respondents could not say or did not perceive that their company's vision/strategy was clear. Many respondents $(n=17)$ were also fully confident that they could suggest improvements related to sustainable practices in the company they worked for. Furthermore, 19 respondents fully agreed that their suggestions for improvements were considered. Such figures paint quite a positive picture of the companies' mindsets and designers' opportunities to influence company practices. However, company size seems to play a role here. Generally, designers from micro- and small-sized companies reported slightly more positive answers than designers from larger companies. The following quote portrays fertile circumstances in a medium-sized company in which the company mindset supports sustainable design: " $\mathrm{I}$ ' $\mathrm{m}$ in a happy situation because at my workplace, responsibility and sustainability are considered strategically. I design products that are long-lasting in terms of aesthetics and usability. When defining timeless details and silhouettes, the whole team, and perhaps surprisingly the feedback from sales, help me." Yet, the practices differed greatly from one company to another. Even though the companies targeted for this study all had sustainable visions, they did not necessarily operate in a manner that might be expected of sustainable-minded companies. For example, one respondent reported working for a trend-driven company in which sustainable practices at the level of product design did not seem to reflect a sustainable mindset. While this specific company had its own corporate social responsibility team, which made sure that the company engaged with responsible factories and that a certain percentage of materials was organic, the sustainable design practices seemed limited to "choosing recyclable paper labels and using recyclable paper for printing". 


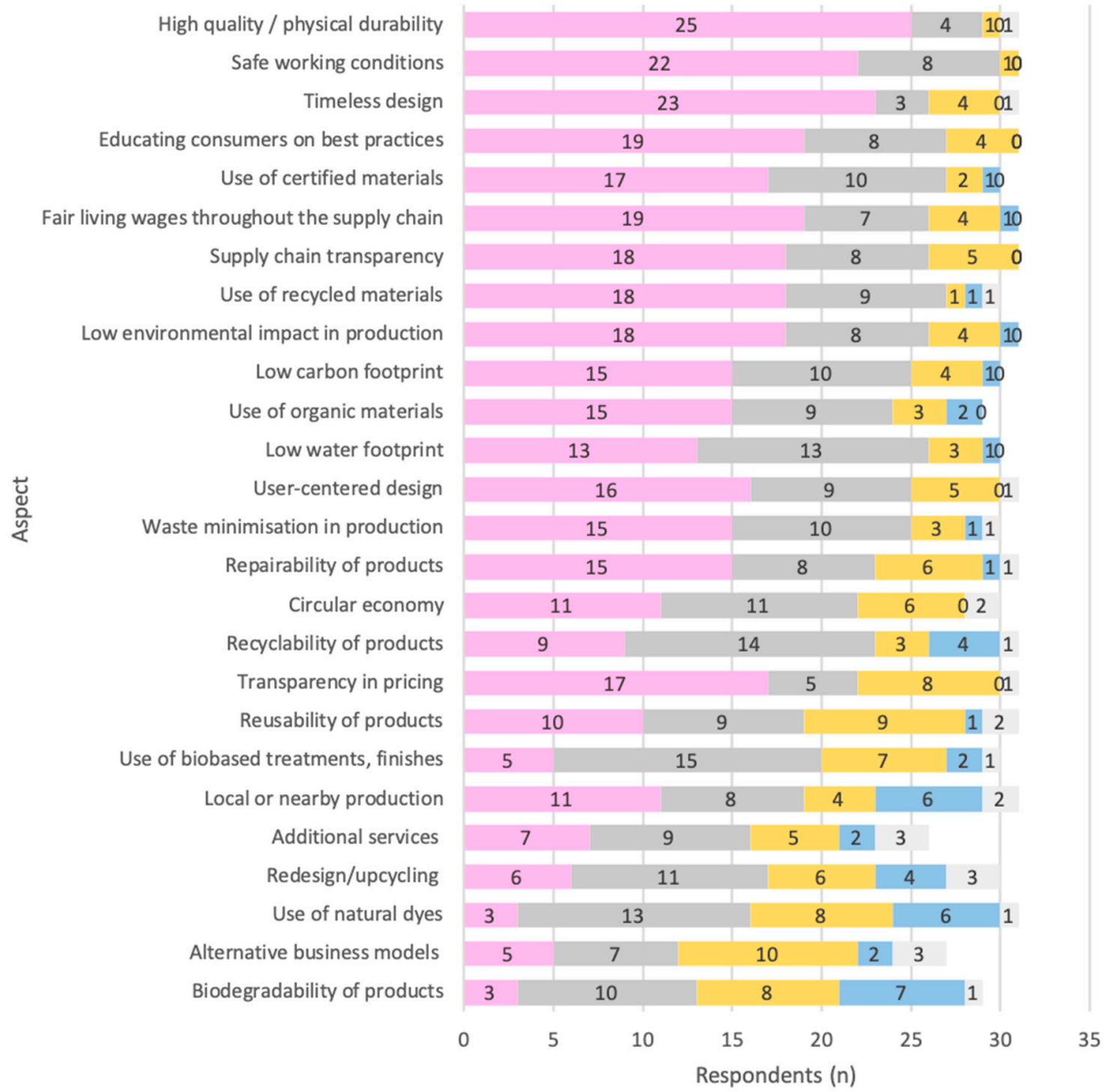

\footnotetext{
Very important. This is in the core of the company's philosophy.

- Important. We are working or aiming to work on it.

- I don't know or I can't say.

= The issue is acknowledged but it's not so important.

Not at all important. The issue is totally ignored.
}

Figure 2. How important are the following aspects in the company you work for? Source: Author.

The company mindset may also impact employees at a more emotional level, as one respondent described: "I am in constant inner conflict in my work because even if I feel like working for a good cause and for better consumption alternatives, I still encourage consumption. This is part of my own experience of how responsibility or sustainability appears (or feels internally) in my design work because I know that we could basically do more." This quote not only demonstrates the conflict between the company mindset and the employee's own standpoint, but also how strictly the designer is bound to the company's values and operations. This argument is supported by the following observation. When the designers were asked to describe how they integrated sustainability into their own design process, many respondents $(n=17)$ deviated from describing their own work as a designer to describing how sustainability was integrated in the company practices more generally by referring to "us", "we", "our company", "our production", etc. These observations reflect how intertwined the design practices are with the company mindset. As some 
designers described, the design choices they made "considering the company culture and the operational environment" were based on the "Creative Director's advice", and "followed the collection brief".

Here it is important, however, to look at the survey sample, which included 14 respondents from micro-sized companies. In the survey, 14 respondents reported working in leading positions, such as founders, owners and/or CEOs, which presumably gives these designers more power and the ability to influence company practices. While these positions carry more responsibility in terms of general company strategy and operations, they also include a varied set of tasks beyond design, such as administration and coordination between different operations. One respondent from a micro-sized company described the multiplicity of tasks as follows: "I am involved in every aspect of the business. I founded the business with my partner, we run the business together. We do everything from dyeing our own fabrics, selling to wholesale clients, selling to customers, staffing pop up shops and answering emails. As well as posting on social media, marketing and building and maintaining our own website. We are also responsible for raising funding for the company."

Despite the varied responsibilities and roles discussed above, the answers indicate that the core task of designers is still to design products and collections, as most of the respondents described $(n=26)$. This process is often a combination of visual/artistic elements (prints, colours, cuts and other details) and technical elements (trims, structures and measurements) that are necessary from a functionality point of view. Preparing technical drawings and specification sheets (including all possible product details) for the manufacturers is a significant part of the process. Considering all of these multiple details takes time, and considering them from a sustainability perspective is even more laborious. As sustainability is such a complex and fluid issue, exploring different alternatives is time-consuming. Yet, as many responses indicated, designers lack the time to properly reflect on their design decisions. "The collection requirements and schedules are so tight that you don't always have the energy to search for and think about sustainable alternatives", pointed out one respondent.

\subsection{Sustainability in the Design Process}

In the survey, the practical design work was mainly addressed through open-ended survey questions. These questions dealt with sustainability in the design process, as well as the challenges and needs that designers face in this respect. Through content analysis we were able to identify three key factors, which (next to company mindset) seemingly determined the designers' work from a sustainability perspective. These were: (1) strong material focus; (2) the ethos of product longevity; (3) (lack of) knowledge. These factors support the findings of the preliminary study and they are discussed, respectively, in this section. Table 4 provides further support for the discussion and summarises the mostly often mentioned approaches in the designers' textual responses when asked how they integrate sustainability into their design practice.

\subsubsection{Material Focus}

Materials dictate the discussion of sustainable design practices in many respects. Environmental implications and material availability are the main concerns that emerged from the textual data. From the environmental perspective, choosing organic, recycled, certified and surplus materials is the most apparent way for designers to approach sustainability $(n=18)$. "All materials in the collection have some sustainable element, so they are made of recycled fibres or organic cotton, some of which come from a Fairtrade partner", wrote one designer. Others described their choice of materials in even more detail: "I choose only GOTS-certified natural fibres and responsibly produced cellulose fibres such as Tencel or EcoVero viscose." The strong focus on sustainable materials is consistent with the respondents' definitions of sustainability and the sustainable approaches of the companies. 
Table 4. How do you integrate sustainability into your design practice?

\begin{tabular}{|c|c|c|}
\hline Approaches & Respondents ( $n$ ) & Examples \\
\hline Material choices & 18 & $\begin{array}{l}\text { Organic, recycled, surplus, durable, high-quality, } \\
\text { GOTS-certified, Fair Trade }\end{array}$ \\
\hline Product longevity & 9 & $\begin{array}{l}\text { Long-lasting, durable, high-quality, reusable } \\
\text { garments }\end{array}$ \\
\hline Timeless design & 9 & Classic, aesthetically long-lasting \\
\hline Fit for purpose & 8 & $\begin{array}{l}\text { Product serves function, suitable material choices, } \\
\text { "a reason for being made" }\end{array}$ \\
\hline Waste minimisation & 8 & $\begin{array}{l}\text { Zero waste, pattern making, packaging, "We have } \\
\text { to use all that we have in stock" }\end{array}$ \\
\hline Upcycling & 6 & $\begin{array}{l}\text { Surplus, end of roll fabrics, "waste fabrics from } \\
\text { previous collections" }\end{array}$ \\
\hline Repairability & 3 & $\begin{array}{l}\text { "The structures must be repairable", "The product } \\
\text { can be repaired during use" }\end{array}$ \\
\hline Recyclability & 3 & $\begin{array}{l}\text { "Ensuring that the garments can be recycled at } \\
\text { the end of their life cycle" }\end{array}$ \\
\hline
\end{tabular}

Another key concern related to materials was material availability. When asked what the designers' themselves would need in order to make more sustainable decisions, only five respondents mentioned a demand for more fabric options. However, when we compared the open-ended responses with the simple numeric data, we found that roughly half of the respondents stressed the limited material offering. Fourteen respondents agreed fully or to some extent with the claim that the offering of sustainable materials (organic, recycled or certified) is poor. When asked about the challenges that designers faced when designing long-lasting or recyclable garments, the issue of material availability became even more apparent. Regarding long-lasting designs, the availability of high-quality materials (and their price) was a concern for seven respondents, whereas 22 respondents emphasised a lack of materials suitable for recycling. The following excerpt by one designer crystallises the current contradiction between material offering and limitations in material recycling: "An easily recyclable garment is made of one material and includes only a few details such as zips or buttons. Today most fabrics designed for the clothing industry consist of more fibres, but material blends are currently difficult to recycle." On the other hand, some respondents wrote that mono-materials were not so desirable either because they are not as durable.

It becomes apparent that the main issue with materials centres on trade-offs. The excerpts above and below depict this situation, as well as the variety of compromises that designers might be required to make. "Mono-materials don't match our company strategy from the perspective of maintenance, comfort and sustainability. We are waiting for the recycling of blends to develop further", one respondent described. Likewise, "[t]he durability of materials is the biggest challenge. No fabric lasts forever and the most durable fabrics, on the other hand, usually contain some synthetic fibres, which I try to avoid for ecological reasons", wrote another designer.

It is difficult to say how much influence designers have, specifically in terms of material choices. One designer wrote that they can only suggest materials, while another designer described making fabric decisions together with the brand manager. The following excerpt encapsulates well how material choices are strongly dependent on the company's overall image and mindset, either limiting or supporting designers (or product development teams) to make conscious material decisions: "When we start to design a new collection, we have to use all that we have in stock, one of a kind pieces are important in our store." 


\subsubsection{Ethos of Product Longevity}

Based on the analysis, the next key determinant in sustainable design practices is product longevity. When asked how designers integrate sustainability in their work, product longevity was one of the most referred to approaches in the textual responses $(n=13)$. In addition, when asked about how familiar designers are with various sustainable design strategies, 20 respondents reported actively applying the design for longevity approach.

In the textual responses, we could identify two parallel discussions linked to product longevity-technical and aesthetical. From the technical perspective, the designers highlighted a couple of approaches, mainly the use of high-quality materials, and materials that truly serve the purpose. In addition, many respondents stressed the functional product aspects, meaning that a product should serve a purpose and "have a reason for being made". Paying attention to product structures is also important in terms of functionality, and hence longevity. On the other hand, product repairability, which is a significant feature supporting longevity, was referred to by only three respondents.

Regarding aesthetics, eight respondents mentioned aiming for timeless or classical design. "Long-lasting product aesthetics is the aspect designers can influence the most", one designer stated. Based on the simple numerical data, even more designers seemed to actively consider timeless design in their practice $(n=22)$. Similar figures were also reported in terms of slow fashion $(n=20)$.

Generally, product longevity and timeless design seemed well-embedded in the practices of most companies. The designers' views of company practices further support this claim. Twenty-nine respondents perceived high quality/physical durability as an important or very important aspect for their company. Timeless design was considered almost equally as important, as 26 respondents reported that their company already worked or aimed to work on this aspect.

Even though product longevity was clearly present in the designers' work in one way or another, the following question arose: How can we ensure product longevity? When asked about the challenges regarding long-lasting design, the respondents discussed the impact of trends and the current culture of consumption. According to some, consumers do not value garments enough, "constantly demand new and cheap", and are not ready to pay the price, which is usually higher than those for conventional non-sustainable products. These aspects push some designers to question the longevity of garments, regardless of long-lasting intentions. Six respondents, for example, questioned how to make sure a product remains aesthetically pleasing. Meanwhile, some admitted they were uncertain of the actual usage time of their designs. One designer wrote, "I don't really believe in timeless design, but I would like the garments I design to remain visually interesting and topical throughout their lifecycle." A more practical example was given by another respondent, who said "The biggest challenge is to create a design with a nice print that you still want to wear in 10 years' time." The impact of trends is significant and tends to make consumer behaviour unpredictable. Meanwhile, trends also still influence designers who knowingly try to avoid them. As one respondent described, "I really strive to develop designs that are somewhat timeless and could potentially remain in one's wardrobe for many seasons. It is hard to completely wash out the influence of trends: living in a big city they are all around and I sometimes realise that seeing them all around me influences my work as a designer."

Similarly, some designers $(n=5)$ wrote about their uncertainty regarding physical durability and admitted that their companies faced difficulties in testing materials (often for financial reasons). As one designer described, "The main challenge [regarding product longevity] is the lack of testing possibilities." This aspect is especially pertinent in small companies, many of which seem to rely on "homemade methods" such as "test-wears". Five of the represented companies relied purely on technical laboratory tests for materials, whereas 11 companies only conducted practical test-wears for their products. Only three companies implemented both laboratory tests and test-wears to ensure product longevity. This indicates that roughly half of the companies in the survey tested their materials/products in one way or another. The other half seemed to rely on the information regarding material specifications, as well as on hand-feel and visual perception of the material. However, 
technical material information may also be misleading. As one designer pointed out, "It's difficult to know the durability, wear and tear and pilling, if we have a new material that we haven't used before. Even if all our materials have a so-called spec sheet, from which you can check, for example, abrasion resistance, we have had surprises."

\subsection{3. (Lack of) Knowledge}

When asked what the designers would need in order to make more sustainable decisions in the design process, knowledge $(n=10)$ was the most referred to aspect. In this context, the designers referred once again to sustainable material options, and to the question of what materials are the most sustainable. As some designers pointed out, it is difficult to compare the sustainability of different materials because not enough transparency and material studies are available. The following excerpt encapsulates the insufficiency of current knowledge: "The information that is quickly and efficiently accessible to make design decisions is not openly available in my opinion. There are a lot of books, case studies and platforms that provide different and perhaps more conceptual info, but none that gives you clear and effective guidelines or the possibility to evaluate your processes as a designer."

Uncertainties also occur in terms of product longevity and recycling. As shown in the previous section, it may be difficult to obtain not only reliable knowledge on the technical durability of materials, but also on the actual usage time of garments. Similarly, there are multiple questions concerning product recycling. When asked about the challenges faced when aiming to design recyclable garments, a common concern was which materials to choose or to avoid. As one respondent described, "Because there is no recycling infrastructure, it is difficult to know the levels at which recycling works and how. What does the future system require? For example, how should we separate fibres in the near future?" Based on the simple numerical data, however, most respondents were fully $(n=11)$ or somewhat $(n=12)$ confident that they knew what aspects to consider if they wanted to design a product suitable for textile recycling. This seems contradictory, as recycling infrastructure is still under development and only general requirements have been provided. Likewise, all the designers reported being fully $(n=17)$ or somewhat $(n=14)$ confident that they knew what aspects to consider if they wanted to design a long-lasting product. Once again, this finding is somewhat contradictory in terms of the lack of knowledge on technical durability and actual usage time.

Generally, as the excerpts above demonstrate, the issue of knowledge seems to be dependent on external factors. Internally, however, the companies were able to help designers make conscious decisions. For example, most respondents agreed fully $(n=15)$ or to some extent $(n=10)$ with the claim that their company had some sustainable guidelines in place. Dedicating personnel to sustainability issues could also be one option, but in light of the following figures, this practice has room for improvement. Half of the respondents $(n=15)$ agreed fully or to some extent that their company had enough personnel dedicated to sustainability issues, while 10 respondents reported that the company had used external consultancy to help improve their sustainable practices.

Next to the companies' efforts, the designers themselves played an important role in acquiring new knowledge. Most respondents agreed fully $(n=11)$ or to some extent $(n=16)$ with the statement that they had dedicated free time to sustainability-related issues. Presumably for this reason, most respondents also felt confident $(n=15)$ or somewhat confident $(n=12)$ about their own sustainability expertise and ability to make knowledge-based decisions when designing new products.

As seen in the excerpt above, some designers were clearly aware of various studies and platforms that have been developed in recent years to assist designers in implementing sustainability in their practices. In the survey, this aspect was further addressed by asking designers how familiar they were with various sustainable design strategies and tools. Based on the simple numerical data, we conclude that, although the designers were well-aware of the sustainable design strategies, they did not actively apply them, apart from those that supported the ethos of product longevity, in other words, timeless design, design for longevity, slow fashion and multifunctionality. This can be seen in Figure 3, which indicates how familiar the survey respondents were with various sustainable design strategies. The strategies are presented in 
the figure in order of popularity and are called "approaches" (as the authors thought this wording might be more appropriate and easier to comprehend by the survey respondents).

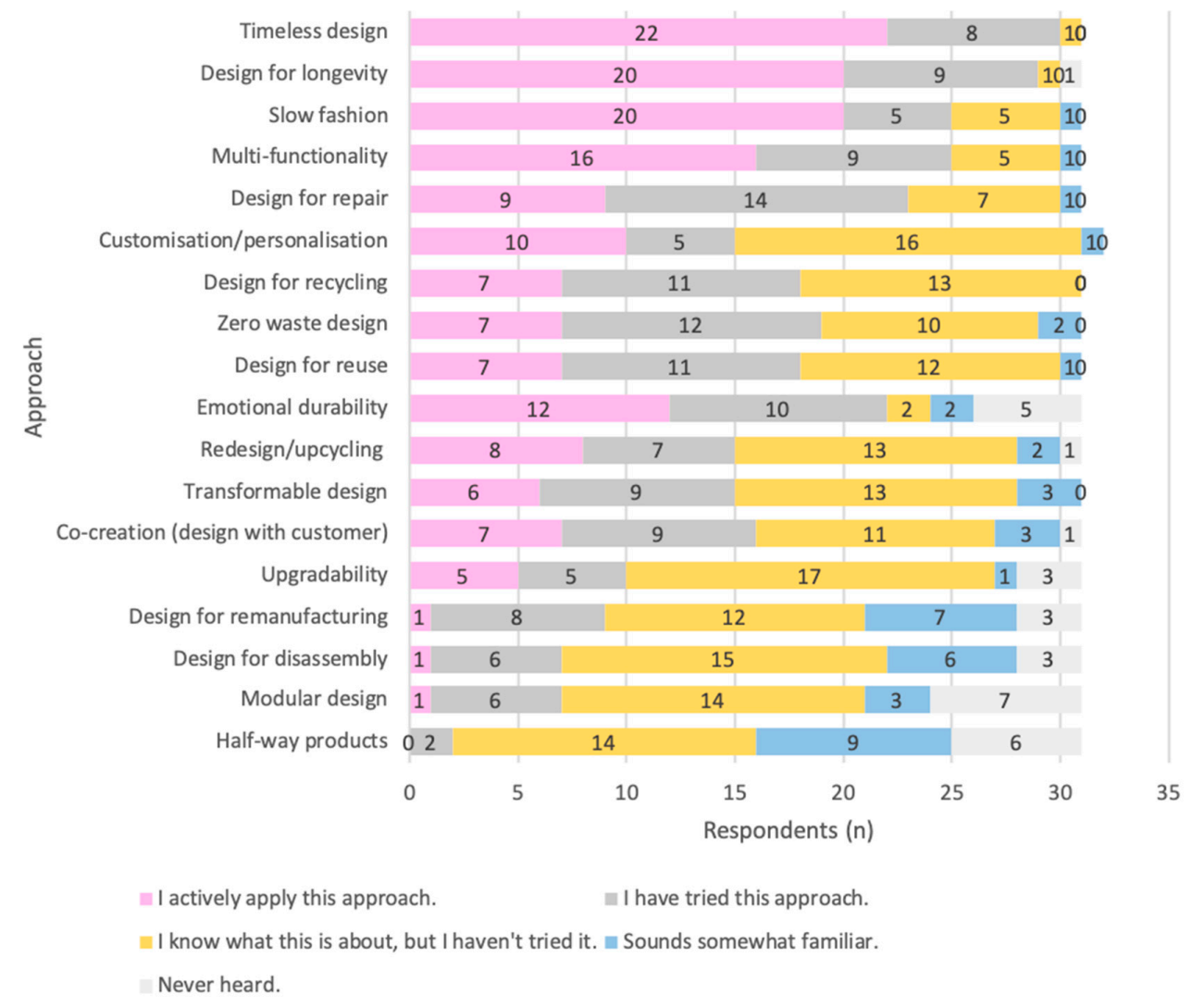

Figure 3. How familiar are you with the following design strategies/approaches?

Figure 4 shows the designers' familiarity with some currently available sustainable design tools, which aim to support sustainable and/or circular clothing design. As seen in the figure, the designers were not so well acquainted with sustainable design tools. This can be well demonstrated by the HIGG Index, which was the best-known tool among the survey respondents. Only three respondents reported actively using it, and four reported that they had tried it. Most of the respondents $(n=18)$ seemed to know what the tool was, but nine respondents had never heard of it. Generally, the tools developed by universities were the least known among designers.

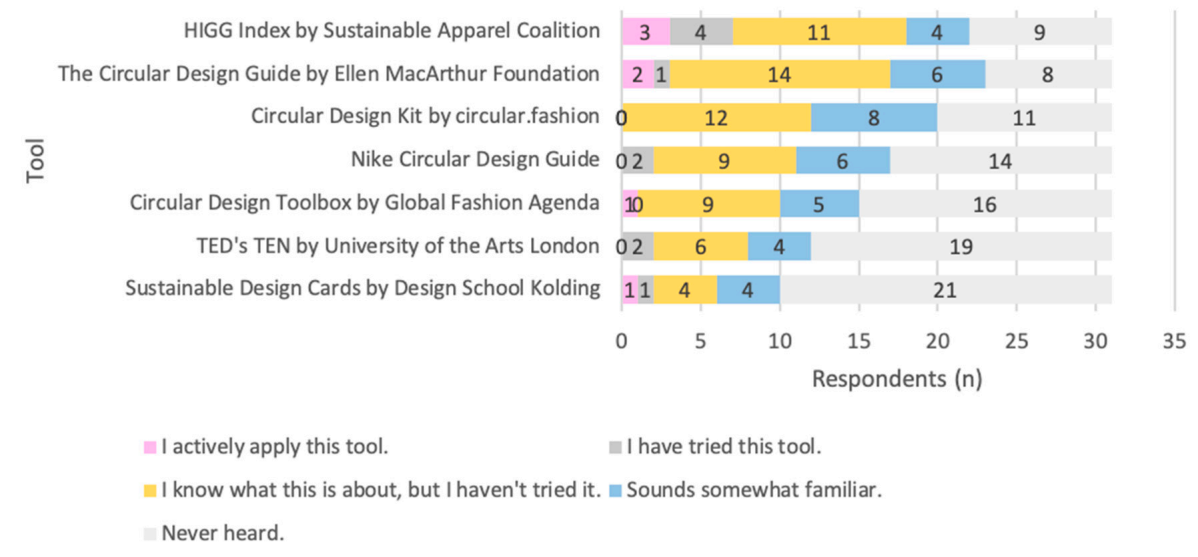

Figure 4. How familiar are you with the following design tools and guides? 


\section{Discussion}

The primary objective of this study was to deepen the understanding of sustainable clothing design practices in sustainable-minded companies. Applying the mixed-method approach, based on the sequential exploratory strategy, allowed us to investigate this issue using different methods that complemented each other. Whereas the expert interviews included only a few deep and nuanced descriptions, guiding the researchers to polish their questions, the survey broadened the study in the form of short concise responses and numerical evidence. This section mixes the results of these phases and offers a joint discussion of their implications.

\subsection{Within and Beyond Design Practice}

Based on both phases of the study, sustainable design practices largely focus on sustainable material choices. Why the materials steer this discussion is understandable. Material is the embodiment of a product and it is probably the easiest and most controlled (certified) way to integrate sustainability into its design. Material standards are also an easy way to communicate environmental considerations to consumers. In addition, materials directly impact the quality and physical durability of a product. From the perspective of the circular economy, which increasingly diffuses into sustainable fashion discourse, materials, their combinations and various surface treatments are the most crucial factors in terms of recycling [62]. Meanwhile, the lack of suitable materials has also been identified as the strongest obstacle to making business practices more sustainable [77]. Even though the focus on sustainable materials (especially organic cotton) started already in the early 1990s [78], it is still a central concern among businesses. Choosing sustainable materials is, however, a limited view to sustainability. As Fletcher points out, material choice is only the initial step and does not solve the problem of overproduction and overconsumption [34]. Where the materials originally come from, how they are produced and under what circumstances, are rarely matters for designers to decide. Obviously, designers who are involved in material sourcing can actively interact with suppliers and request alternatives based on certificates or standards that fulfil certain criteria regarding environmental, human and/or animal welfare. Still, many designers work only on the basis of suggesting ideas, as those higher in rank make the final decisions.

While some literature suggests that designers make all the decisions throughout the design process [79], we argue against this. Apart from designers working in managerial positions, myriad environmental and social impacts lie beyond clothing designers' reach. For example, social responsibility was referred to mostly when designers were asked to define sustainability, described in Section 4.1. However, there were no indications that designers (unless in leading positions) would be responsible for coordinating where the production took place, let alone the working conditions of garment factories. Based on our findings, social responsibility is integrated into companies' overall operations, but it has no linkage to design practice apart from materials that fulfil certain ethical standards. These are questions to be dealt with at a higher level in the company hierarchy. Similarly, many environmental concerns do not touch the design work. Questions, such as "What source of energy is utilised in the production phase of a garment?" or "How are the products distributed within the supply chain?", go beyond the design practice. Still, these are critical issues from the perspective of greenhouse gas emissions (GHG) and climate change [80]. Although some of these aspects could be tackled through better collaboration with suppliers and stricter legislation, regulation and incentives are also needed. Textile chemical bans exemplify how regulation has induced sustainable practices in the field of textiles in the past [81]. Such determination and policy intervention are required when it comes to issues such as GHG emissions and garment overproduction.

Against these notions, we would argue that clothing designers are not as determining figures as the earlier literature suggests. Company size is likely to play a role here [17], yet more research on this aspect is necessary. Despite company size, a designer is "ultimately responsible for creating the collection-From the initial inspiration and design stages to overseeing first samples for selling" [79] (pp. 8-53). Here, the main aspects that designers can influence are material choices, product aesthetics 
(colours, prints or silhouettes) and technical features (product structure, functional details and fit and measurements). These are exactly the same aesthetic and technical attributes that designers must focus on while implementing sustainability in the clothing design process. It is interesting, though, that even if EU-wide rules for product categories, such as household appliances and other energy-using products, exist (Ecodesign Directive) [82], there has not been any regulatory framework for sustainable textiles or garments. The new Circular Economy Action Plan [83], published in March 2020, contributes to this demand with a new sustainable product policy framework. How the future's "ecodesign measures" [83] (p. 13) will play out in the context of fashion, and whether they will actually shape or restrict the working practices of clothing designers, remains to be seen. To implement the new sustainable product policy framework in the industry, close collaboration between the state and the market will be necessary. This will presumably entail more resources from national fashion and textile associations that already work as intermediaries between the industry, government bodies, research institutes and academia.

\subsection{Wishful Thinking}

Even though designers may be perceived as being responsible for all product-related decisions at the production stage, they are greatly dependent on external knowledge, different requirements, and the quantitative evidence of the superiority of certain design strategies, production processes, materials, etc. While life-cycle assessments have been slowly integrated into the fashion sector [84,85], the currently available data do not enable a comparison between fashion products in a way that would be easy to integrate into the clothing design process and help designers make educated decisions. In this respect, the fashion industry remains at least 10 years behind food, building and water industries [84].

As Chapman and Gant also point out, "sustainable design practice is driven largely by assumption, and preconception as to what constitutes best practice" [86] (p. 138). This seems quite accurate in terms of product longevity, which was continuously referred to in both phases of this study. It is assumed that design for longevity translates into a long-lasting garment, but in fact, knowledge of actual product lifetimes is missing. While most designers reported knowing how to design a long-lasting garment, many admitted they did not know how long their designs remained in use. This notion resonates with earlier studies that highlight consumers' unpredictable consumption behaviour [51-53]. This leaves us questioning, in line with Maldini et al. [33,53], whether strategies for longevity can truly diminish new purchases and production volumes. Can unpredictability be taken into account in design? As companies (so far) have no information on the usage phase and real lifecycles of their products, clothing designers can only design sustainability potentials embedded into products. Garments can certainly be designed environmentally and socially responsibly (if relevant knowledge, resources and support are available), but finally, the sustainability of a product is determined by its user. From a technical perspective, designers might well know how to design for longevity, but when moving beyond technicalities, we start sensing wishful thinking. As Chapman and Gant point out, "current understanding of sustainable design is unhelpfully fragmented and disparate, while also being based largely on what people think is best" [86] (p. 137).

In this respect, better understanding of customer behaviour would be essential; however, as Fletcher notes, "the ability of a traditional design process to reach into the life world of the user and influence behaviour appears to be weak" [51] (p. 235). Thus, untraditional approaches are needed. As Gwilt suggests, engaging with user studies during the product design and testing phases could feed new innovations [87], but in the current system and with the current resources available per one product, this may feel like a remote possibility. Nevertheless, it would be worth studying how user studies could be implemented in the design phase, in which time is often scarce. Meanwhile, additional services such as repair and maintenance could provide another way to help companies expand their understanding of their customers' needs and garment lifecycles [25,52].

The sense of wishful thinking connects us back to the designer's role and influence. As demonstrated, it seems that the sustainable design practices in the represented companies were predominantly limited to 
incremental product-focused approaches. Hence, they did not challenge the wider industry practices and the current fashion system. Even though some designers referred to lifecycle thinking when defining sustainability, as detailed in Section 4.1, and reported applying various strategies, noted in Section 4.4.3, a holistic approach that considers the whole garment lifecycle may be difficult to implement in practice. This corresponds with the study by Lawless and Medvedev [13]. Eventually, a sustainable design process tends to be about constant trade-offs between sustainability and profit, long-lasting and recyclable, or high-quality and consumer price. In these circumstances, the designer's role appears quite restricted. While some research may romanticise designers as the key agents or drivers of change, the decisions within the design process are made within a limited design space, especially in larger companies. As Chapman and Gant note, "much of the sustainable design debate is dominated by academics and so far, the content of this discussion has yet to fully penetrate the world of practising designers", who "ordinarily deal with more immediate issues" [86] (p. 138).

Although new knowledge on sustainable design practices is continuously increasing, it seems that fashion industry practices are not keeping pace. Given that theoretical understanding (supported by the empirics) and practical design work (often under a predetermined space in a company environment) both play considerable roles in sustainability discourse, multiple questions remain: How can we bridge the gap between scholarly work and clothing design practice? (i.e., How can we translate theoretical knowledge into a feasible, workable form that is beneficial for designers?); To what extent is academic knowledge needed to support design?; What is the actual role of sustainable fashion design research in this respect?; What constitutes the best practices in the first place if empirical evidence is largely missing?

\subsection{Limitations and Future Research}

The study represents a constantly changing field and provides only a snapshot [70] (p. 137) of sustainable design practices in a certain context. This is especially true with regard to the research sample, which included 36 clothing designers. This may seem a modest figure outside sustainable fashion research but, based on the specificity and sensitivity of the topic, the number of respondents is significant compared to earlier studies that focus on sustainable fashion from the designer's perspective. What this study clearly shows is that recruiting clothing designers to participate in academic research on a sensitive topic is challenging.

Another concern is undoubtedly the geographical distribution of the respondents. Even though the aim was to reach designers from different parts of Europe, more than half of the research participants came from Finland, which gives the study a Northern European emphasis. Regarding the survey, it would have been interesting to compare the responses based on geographical location, but this was not considered appropriate due to the small sample. Thus, we cannot be sure how the overrepresentation of Finland impacted the results. It is illuminating, however, that although the circular economy plays a significant role in Finland's political agenda, the survey results mirrored relatively small company efforts towards a circular economy, apart from the design for longevity approach and the usage of recycled materials.

The methods also present certain limitations. In the ideal case, the study would have included many more interviews in order to gain richer and more nuanced data. Due to the challenges in recruitment, the online survey provided alternative means to reach a more representative sample, while expanding on the experiences and observations in the preliminary phase. The limitation of the survey, however, is that one cannot clarify the questions to the respondent. There is always the possibility of misinterpretation when answering the survey questions as well as when interpreting the results.

This study could not provide definitive statements on how much decision-making power designers possess at different phases of design and production processes. This is a valid question for further investigation to better understand designers' impact on the much-needed transition to sustainability (and circularity). In addition, the same question should be asked of people who work in coordination and managerial positions in fashion companies. Such research could help address the shared responsibilities in the company context: Who has (or should have) the relevant knowledge? Who has the power to 
act? Where should more sustainability education be directed and to what extent? Moreover, studies of governments' potential to support the emergence of sustainable fashion market would be beneficial to fully understand the roles and responsibilities of different stakeholders when aiming to transform this industry sector.

In addition, even if this study did not compare design practices on the basis of company size or age, it hints at differences. A similar survey could be useful to further extend the data set for the purposes of comparing design and company practices based on various variables. Furthermore, a somewhat similar survey among companies that do not consider sustainability important could provide an avenue for future research. Understanding the specific requirements and demands of different kinds of companies would be crucial from the perspective of support. For example: What would sustainable-minded companies of different sizes require in order to more quickly improve their practices? What would non-sustainable companies need in order to start implementing sustainability in the first place? These questions further relate to the discrepancy between the theoretical knowledge and practice highlighted in the previous section. To address these knowledge gaps in future research, it might also be beneficial to review how other fields (beyond design) have managed to implement corporate social responsibility and research-based knowledge in practice.

\section{Conclusions}

This study was conducted to investigate the design practices of sustainable-minded clothing companies through a mixed-method approach and addressed the following questions: "How is sustainability integrated in the design practices of sustainable-minded clothing companies?" and "What is the clothing designer's role in this respect?" The study began with five expert interviews in the form of a preliminary study, which further guided the authors to conduct a survey within a wider sample of practising clothing designers. The findings indicate that designers approach sustainability mainly by choosing sustainable materials and by considering various details and structures that are meant to support product longevity. These practices are in line with the companies' sustainable approaches as well as how the designers define sustainability. However, as these approaches are limited, they do not challenge the current fashion system.

The findings also highlight the narrow role of designers despite the much referred to statement that $80 \%$ of the environmental and social impacts of a product could be influenced already at the product design and development phase. While it might be true that the decisions made in this phase influence $80 \%$ of the environmental and social impacts of the product, a designer does not make all of these decisions. A designer works in a restricted space, which is framed by company strategy and mindset, the designer's role in the company, the time allocated for the design process and the designer's limited knowledge base. In addition, it is noteworthy that the understanding and implementation of the circular practices is quite poor, even though the circular economy has recently become the main endeavour of the EU policy. These findings suggest that the commitment to move towards more sustainable fashion design and manufacturing needs significant strategy work at the company level, supported by new regulatory frameworks for the sustainable design, use and disposal of products. Even though different government programmes might generally mirror the new Circular Economy Action Plan [83] (as is the case in Finland), closer engagements between the fashion industry and National Commissions on Sustainable Development are essential to reveal the discrepancies, limited knowledge and wishful thinking within this industry sector.

To conclude, designers struggle with the same obstacles to sustainability that were identified many years ago. What has actually happened in recent years? Even though academic research on this area has expanded and tools to support sustainable design have been developed, to a large extent, this knowledge has not been included in design and industry practices. On the other hand, we can still question what the best sustainable practices are. The reality is, however, that sustainable solutions are not implemented quickly enough, meaning that we are not even close to a real change in this industrial sector. Based on this study, we propose closer collaboration between academic researchers, industry practitioners, policy makers and consumers in order to much more rapidly transform the fashion industry. 
Author Contributions: Conceptualisation, E.K. and K.N.; Methodology, E.K; Writing-Original draft preparation, E.K.; Writing-Review and editing, E.K. and K.N.; Visualisation, E.K.; Supervision, K.N.; Funding acquisition, E.K. and K.N. All authors have read and agreed to the published version of the manuscript.

Funding: This research was supported by the Jenny and Antti Wihuri Foundation and the Academy of Finland's Strategic Research Council, grant number 327299/FINIX consortium.

Acknowledgments: We would like to thank the anonymous reviewers for their valuable feedback on the earlier drafts of this article, as well as the members of the Fashion/Textile Futures research group for their helpful comments during the writing process.

Conflicts of Interest: The authors declare no conflicts of interest.

\section{Appendix A}

Table A1. Survey design.

\begin{tabular}{|c|c|}
\hline Question & Question Type \\
\hline What is your education? & Multi-selection matrix \\
\hline What is your current position in the company you work for? & Multi-selection \\
\hline $\begin{array}{l}\text { How would you describe your role and responsibilities in the company? What do } \\
\text { you practically do? }\end{array}$ & Open-ended \\
\hline How many years have you worked in the clothing industry as a designer? & Selection \\
\hline Do you have other work experience in the clothing industry other than design? & Selection and free text field \\
\hline What does sustainability mean to you as a designer? & Open-ended \\
\hline How do you integrate sustainability into your design practice? & Open-ended \\
\hline $\begin{array}{l}\text { Below you can find several claims. Do you agree or disagree when you think } \\
\text { about your work as a designer? }\end{array}$ & Scale selection and free text fields \\
\hline How familiar are you with the following design strategies/approaches? & Scale selection and free text field \\
\hline How familiar are you with the following design tools and guides? & Scale selection and free text field \\
\hline What are the biggest challenges for you if aiming to design long-lasting garments? & Open-ended \\
\hline What are the biggest challenges for you if aiming to design recyclable garments? & Open-ended \\
\hline $\begin{array}{l}\text { What would you need as a designer in order to make more sustainable decisions } \\
\text { in the design process? What kind of requirements or wishes do you have? }\end{array}$ & Open-ended \\
\hline In which country is the company located? & Open-ended \\
\hline How would you shortly describe the company's purpose? & Open-ended \\
\hline In which sector(s) does the company operate? & Multi-selection and free text fields \\
\hline Through which operations does the company sell their products or services? & Multi-selection and free text fields \\
\hline Where are most of the companies' products manufactured? & Multi-selection and free text fields \\
\hline How long has the company been in operation? & Selection \\
\hline What is the company size? & Selection \\
\hline How important are the following aspects in the company you work for? & Scale selection and free text fields \\
\hline How do you estimate the quality of a fabric or a garment? & Open-ended \\
\hline From your point of view, what is bad, average and high quality? & Open-ended \\
\hline $\begin{array}{l}\text { What kind of quality do you aim for within your company? What kind of } \\
\text { methods do you use in order to achieve that level? }\end{array}$ & Open-ended \\
\hline
\end{tabular}

\section{References}

1. Farley Gordon, J.; Hill, C. Sustainable Fashion: Past, Present and Future; Bloomsbury Academic: London, UK, 2015.

2. Wallinger, S.R. A history of sustainability in fashion. In Routledge Handbook of Sustainability and Fashion; Fletcher, K., Tham, M., Eds.; Routledge: Abingdon, UK, 2014; pp. 151-159. 
3. UN Climate Change. Fashion Industry Charter for Climate Action. 2018. Available online: https:/unfccc.int/sites/default/files/resource/Industry\%20Charter\%20\%20Fashion\%20and\%20Climate\% 20Action\%20-\%2022102018.pdf (accessed on 11 February 2020).

4. Cobbing, M.; Vicaire, Y. Fashion at the Cross Roads: A Review of Initiatives to Slow and Close the Loop in the Fashion Industry. Greenpeace e.V.: Hamburg, Germany, 2017. Available online: https://storage.googleapis.com/planet4-international-stateless/2017/09/76e05528-fashionat-the-crossroads.pdf (accessed on 11 February 2020).

5. Lehmann, M.; Arici, G.; Robinson, F.; Kruse, E.; Taylor, A.R. CEO Agenda 2020: Eight Sustainability Priorities for the Fashion Industry. Global Fashion Agenda, 2020. Available online: https://globalfashionagenda.com/ ceo-agenda-2020/\# (accessed on 31 January 2020).

6. Global Fashion Agenda. 2020 Circular Fashion System Commitment-Status Report 2019. Available online: http://globalfashionagenda.com/commitment/\# (accessed on 9 April 2020).

7. Lehmann, M.; Arici, G.; Boger, S.; Martinez-pardo, C.; Krueger, F.; Schneider, M.; Carrière-Pradal, B.; Schou, D. Pulse of the Fashion Industry 2019 Update. Global Fashion Agenda, Boston Consulting Group and Sustainable Apparel Coalition: 2019. Available online: https://globalfashionagenda.com/pulse-2019update/ (accessed on 10 June 2019).

8. Ellen MacArthur Foundation. A New Textiles Economy: Redesigning Fashion's Future. Available online: https://www.ellenmacarthurfoundation.org/assets/downloads/publications/A-NewTextiles-Economy_Full-Report.pdf (accessed on 5 December 2017).

9. Fletcher, K. Craft of Use: Post-Growth Fashion; Routledge: Abingdon, UK, 2016.

10. Tischner, U.; Charter, M. Sustainable product design. In Sustainable Solutions: Developing Products and Services for the Future; Charter, M., Tischner, U., Eds.; Greenleaf Publishing: Sheffield, UK, 2001; pp. 118-139.

11. European Commission. Sustainable Product Policy. Available online: https://ec.europa.eu/jrc/en/researchtopic/sustainable-product-policy (accessed on 3 April 2020).

12. Hur, E.; Cassidy, T. Perceptions and attitudes towards sustainable fashion design: Challenges and opportunities for implementing sustainability in fashion. Int. J. Fash. Des. Technol. Educ. 2019, 12, 208-217. [CrossRef]

13. Lawless, E.; Medvedev, K. Assessment of sustainable design practices in the fashion industry: Experiences of eight small sustainable design companies in the Northeastern and Southeastern United States. Int. J. Fash. Des. Technol. Educ. 2016, 9, 41-50. [CrossRef]

14. Palomo-Lovinski, N.; Hahn, K. Fashion design industry impressions of current sustainable practices. Fash. Pract. 2014, 6, 87-106. [CrossRef]

15. Kozlowski, A.; Bardecki, M.; Searcy, C. Tools for sustainable fashion design: An analysis of their fitness for purpose. Sustainability 2019, 11, 358. [CrossRef]

16. Aakko, M. Artisanal and slow: The case of Anna Ruohonen. In Sustainable Fashion: New Approaches; Niinimäki, K., Ed.; Aalto University: Helsinki, Finland, 2013; pp. 56-67.

17. Delong, M.; Goncu-berk, G.; Bye, E.; Wu, J. Apparel sustainability from a local perspective. RJTA 2013, 17, 59-69. [CrossRef]

18. Gurova, O.; Morozova, D. A critical approach to sustainable fashion: Practices of clothing designers in the Kallio neighborhood of Helsinki. J. Consum. Cult. 2016, 18, 397-413. [CrossRef]

19. Connor-Crabb, A.; Miller, K.; Chapman, J. Design strategies for the eternal reoccurrence of the new. Fash. Pract. 2016, 8, 22-43. [CrossRef]

20. Štefko, R.; Steffek, V. Key issues in slow fashion: Current challenges and future perspectives. Sustainability 2018, 10, 2270. [CrossRef]

21. Connor-Crabb, A.C. Fashion Design for Longevity: Design Strategies and Their Implementation in Practice. Ph.D. Thesis, University of Brighton, Brighton, UK, 2017.

22. Rissanen, T. Zero-Waste Fashion Design: A Study at the Intersection of Cloth, Fashion Design and Pattern Cutting. Ph.D. Thesis, University of Technology, Sydney, Australia, 2013.

23. Han, S.L.C.; Chan, P.Y.L.; Venkatraman, P.; Apeagyei, P.; Cassidy, T.; Tyler, D.J. Standard vs. upcycled fashion design and production. Fash. Pract. 2017, 9, 69-94. [CrossRef]

24. Dissanayake, G.; Sinha, P. An examination of the product development process for fashion remanufacturing. Resour. Conserv. Recycl. 2015, 104, 94-102. [CrossRef] 
25. Karell, E.; Niinimäki, K. Deconstructing the clothing design process for a circular economy. In PLATE Product Lifetimes And The Environment 2019 - Conference Proceedings, Berlin, Germany, 18-20 September 2019; Nissen, N., Jaeger-Erben, M., Eds.; TU Berlin University Press: Berlin, Germany.

26. Sinha, P. Creativity in fashion. J. Text. Appar. Technol. Manag. 2002, 2, 1-10.

27. Gwilt, A. Producing sustainable fashion: The points for positive intervention by the fashion designer. In Shaping Sustainable Fashion: Changing the Way We Make and Use Clothes; Gwilt, A., Rissanen, T., Eds.; Earthscan: London, UK, 2011; pp. 59-73.

28. Fletcher, K. Design, the environment and textiles: Developing strategies for environmental impact reduction. J. Text. Inst. 1998, 89, 72-80. [CrossRef]

29. Fletcher, K. Slow fashion: An invitation for systems change. Fash. Pract. 2010, 2, 259-266. [CrossRef]

30. Niinimäki, K.; Hassi, L. Emerging design strategies in sustainable production and consumption of textiles and clothing. J. Clean. Prod. 2011, 19, 1876-1883. [CrossRef]

31. Gwilt, A. Integrating Sustainable Strategies in the Fashion Design Process: A Conceptual Model of the Fashion Designer in Haute Couture. Ph.D. Thesis, RMIT University, Melbourne, Australia, 2012.

32. Aakko, M.; Koskennurmi-Sivonen, R. Designing sustainable fashion: Possibilities and challenges. RJTA 2013, 17, 13-22. [CrossRef]

33. Maldini, I.; Balkenende, A.R. Reducing clothing production volumes by design: A critical review of sustainable strategies. In PLATE Product Lifetimes And The Environment 2017 - Conference Proceedings, Delft, The Netherlands, 8-10 November 2017; Bakker, C., Mugge, R., Eds.; Delft University of Technology and IOS Press: Delft, The Netherlands, 2017; pp. 233-237. [CrossRef]

34. Fletcher, K. Sustainable Fashion \& Textiles: Design Journeys; Earthscan: London, UK, 2008.

35. Black, S. Eco-Chic.: The Fashion Paradox; Black Dog Publishing: London, UK, 2008.

36. Fletcher, K.; Grose, L. Fashion and Sustainability: Design for Change; Laurence King Publishing: London, UK, 2012.

37. Niinimäki, K. Sustainable Fashion: New Approaches; Aalto University: Helsinki, Finland, 2013.

38. Hethorn, J.; Ulasewicz, C. Sustainable Fashion What's Next? A Conversation about Issues, Practices and Possibilities; Fairchild Books: London, UK, 2015.

39. Gwilt, A.; Rissanen, T. Shaping Sustainable Fashion: Changing the Way We Make and Use Clothes; Earthscan: London, UK, 2011.

40. Gwilt, A. A Practical Guide to Sustainable Fashion. Basics Fashion Design; Fairchild Books: London, UK, 2014.

41. Textiles Environment Design. The TED's TEN. Available online: http://www.tedresearch.net/teds-ten/ (accessed on 5 March 2016).

42. Hur, E.; Beverley, K.; Cassidy, T. Development of an ideation toolkit supporting sustainable fashion design and consumption. RJTA 2013, 17, 89-100. [CrossRef]

43. Sustainable Design Cards. Available online: https://sustainabledesigncards.dk (accessed on 2 April 2020).

44. WRAP. Sustainable Clothing: A practical Guide to Enhancing Clothing Durability and Quality. Waste \& Resources Action Programme, 2017. Available online: http://www.wrap.org.uk/sustainable-textiles/scap/ extending-clothing-life/guides/sustainable-clothing-guide (accessed on 23 March 2018).

45. Kozlowski, A.; Searcy, C.; Bardecki, M. The reDesign canvas: Fashion design as a tool for sustainability. J. Clean. Prod. 2018, 183, 194-207. [CrossRef]

46. Niinimäki, K.; Peters, G.; Dahlbo, H.; Perry, P.; Rissanen, T.; Gwilt, A. The environmental price of fast fashion. Nat. Rev. Earth Environ. 2020, 1, 189-200. [CrossRef]

47. WRAP. Valuing Our Clothes: The True Cost of How We Design, Use and Dispose of Clothing in the UK; Waste \& Resources Action Programme: Oxon, UK, 2012.

48. European Commission. Directive 2008/98/EC on Waste (Waste Framework Directive). Available online: https://ec.europa.eu/environment/waste/framework/ (accessed on 11 February 2020).

49. Cooper, T.; Hill, H.; Kininmonth, J.; Townsend, K.; Hughes, M. Design for Longevity. Guidance on Increasing the Active Life of Clothing; Waste \& Resources Action Programme: Oxon, UK, 2013.

50. Karell, E. Planned continuity: Multi-life garments through modular structures and supplemental services. In Sustainable Fashion: New Approaches; Niinimäki, K., Ed.; Aalto University: Helsinki, Finland, 2013; pp. 110-123.

51. Fletcher, K. Durability, fashion, sustainability: The processes and practices of use. Fash. Pract. 2012, 4, 221-238. [CrossRef] 
52. Laitala, K.; Boks, C.; Klepp, I.G. Making clothing last: A design approach for reducing the environmental impacts. Int. J. Des. 2015, 9, 93-107.

53. Maldini, I.; Stappers, P.J.; Gimeno-Martinez, J.C.; Daanen, H.A.M. Assessing the impact of design strategies on clothing lifetimes, usage and volumes: The case of product personalisation. J. Clean. Prod. 2019, 210, 1414-1424. [CrossRef]

54. Braungart, M.; McDonough, W. Cradle to Cradle: Remaking the Way We Make Things; North Point Press: New York, NY, USA, 2002.

55. Ellen MacArthur Foundation. Towards A Circular Economy: Business Rationale for An Accelerated Transition. 2015. Available online: https://www.ellenmacarthurfoundation.org/assets/downloads/TCE_EllenMacArthur-Foundation_9-Dec-2015.pdf (accessed on 29 December 2016).

56. Niinimäki, K. Fashion in a circular economy. In Sustainability in Fashion-A Cradle to Upcycle Approach; Henninger, C., Panayiota, J.A., Goworek, H., Ryding, D., Eds.; Palgrave Macmillan: Cham, Switzerland, 2017; pp. 151-169.

57. Niinimäki, K. Sustainable Fashion in A Circular Economy; Aalto ARTS Books: Espoo, Finland, 2018.

58. Elander, M.; Ljungkvist, H. Critical Aspects in Design for Fiber-to-Fiber Recycling of Textiles. A Mistra Future Fashion Report. 2016. Available online: http://mistrafuturefashion.com/wp-content/uploads/2016/06/ MFF-report-2016-1-Critical-aspects.pdf (accessed on 28 December 2017).

59. Roos, S.; Sandin, G.; Roos, S.; Sandin, G.; Peters, G.; Spak, B.; Bour, L.S. Guidance for Fashion Companies on Design for Recycling. A Mistra Future Fashion Report. 2019. Available online: https://doi.org/10.13140/RG.2. 2.34374.22083 (accessed on 10 April 2020).

60. Karell, E.; Niinimäki, K. Addressing the dialogue between design, sorting and recycling in a circular economy. Des. J. 2019, 22, 997-1013. [CrossRef]

61. Niinimäki, K.; Karell, E. Closing the loop: Intentional fashion design defined by recycling technologies. In Technology-Driven Sustainability Innovation in the Fashion Supply Chain; Vignali, G., Reid, L.F., Ryding, D., Henninger, C.E., Eds.; Palgrave Macmillan: Cham, Switzerland, 2020; pp. 7-25.

62. Karell, E. Design for circularity: The case of circular fashion. In Sustainable Fashion in A Circular Economy; Niinimäki, K., Ed.; Aalto ARTS Books: Espoo, Finland, 2018; pp. 96-127.

63. Global Fashion Agenda. Circular Design Toolbox. Available online: https://www.globalfashionagenda.com/ publications/\# (accessed on 26 October 2018).

64. Nike Circular Design Guide. Available online: https://www.nikecirculardesign.com (accessed on 24 May 2019).

65. Circular Fashion. Available online: https://circular.fashion/tools/ (accessed on 19 February 2020).

66. Aakko, M.; Niinimäki, K. Fashion designers as entrepreneurs: Challenges and advantages of micro-size companies. Fash. Pract. 2018, 10, 354-380. [CrossRef]

67. Creswell, J.W. Research Design: Qualitative, Quantitative and Mixed Methods Approaches, 3rd ed.; SAGE Publications, Inc.: Thousand Oaks, CA, USA, 2009.

68. Lund, T. Combining qualitative and quantitative approaches: Some arguments for mixed methos research. Scand. J. Educ. Res. 2012, 56, 155-165. [CrossRef]

69. Creswell, J.W.; Plano Clark, V.L. Designing and Conducting Mixed Methods Research; SAGE Publications, Inc.: Thousand Oaks, CA, USA, 2007.

70. Flick, U. An Introduction to Qualitative Research, 4th ed.; SAGE Publications, Inc.: London, UK, 2009.

71. Miles, M.B.; Huberman, M.A.; Saldaña, J. Qualitative Data Analysis: A Methods Sourcebook, 3rd ed.; SAGE Publications, Inc.: Thousand Oaks, CA, USA, 2014.

72. Sourcebook. Available online: http://sourcebook.eu (accessed on 12 December 2019).

73. Weber, R. Basic Content Analysis, 2nd ed.; SAGE Publications, Inc.: Thousand Oaks, CA, USA, 1990.

74. Sitra. A Circular Economy. Available online: https://www.sitra.fi/en/topics/a-circular-economy/ (accessed on 4 May 2020).

75. Finnish Textile and Fashion. Publications. Available online: https://www.stjm.fi/en/publications/ (accessed on 4 May 2020).

76. Elkington, J. Cannibals with Forks: The Triple Bottom Line of 21st Century Business; Capstone: Oxford, UK, 1997. 
77. Niinimäki, K.; Aakko, M. Creative control in sustainable fashion. In Proceedings of the 19th DMI: Academic Design Management Conference: Design Management in an Era of Disruption, London, UK, 2-4 September 2014; Bohemia, E., Rieple, A., Liedtka, J., Cooper, R., Eds.; Design Management Institute: Boston, MA, USA, 2014; pp. 583-600.

78. Niinimäki, K. From Disposable to Sustainable: The Complex Interplay between Design and Consumption of Textiles and Clothing. Ph.D. Thesis, Aalto University, Helsinki, Finland, 2011.

79. Renfrew, E.; Renfrew, C. Basics Fashion Design 04: Developing A Collection; AVA Publishing SA: Lausanne, Switzerland, 2009.

80. Peters, G.; Svanström, M.; Roos, S.; Sandin, G.; Zamani, B. Carbon footprints in the textile industry. In Handbook of Life Cycle Assessment (LCA) of Textiles and Clothing; Muthu, S.S., Ed.; Woodhead Publishing: Cambridge, UK, 2015; pp. 3-30. [CrossRef]

81. Ashford, N.A.; Hall, R.P. The importance of regulation-induced innovation for sustainable development. Sustainability 2011, 3, 270-292. [CrossRef]

82. European Commission. Ecodesign. Available online: https:/ec.europa.eu/growth/industry/sustainability/ ecodesign_en (accessed on 4 May 2020).

83. European Commission. Circular Economy Action Plan: For A cleaner and More Competitive Europe. 2020. Available online: https://ec.europa.eu/environment/circular-economy/pdf/new_circular_economy_action_ plan.pdf (accessed on 4 May 2020).

84. Peters, G.; Granberg, H.; Sweet, S. The role of science and technology in sustainable fashion. In Routledge Handbook of Sustainability and Fashion; Fletcher, K., Tham, M., Eds.; Routledge Ltd.: New York, NY, USA, 2015; pp. 181-190.

85. Sandin, G.; Peters, G.M. Environmental impact of textile reuse and recycling-A review. J. Clean. Prod. 2018, 184, 353-365. [CrossRef]

86. Chapman, J.; Gant, N. Designers, Visionaries and Other Stories: A Collection of Sustainable Design Essays; Earthscan: London, UK, 2007.

87. Gwilt, A. Valuing the role of the wearer in the creation of sustainable fashion. RJTA 2013, 17, 78-86. [CrossRef]

(C) 2020 by the authors. Licensee MDPI, Basel, Switzerland. This article is an open access article distributed under the terms and conditions of the Creative Commons Attribution (CC BY) license (http://creativecommons.org/licenses/by/4.0/). 